\title{
Rearranging Dispatching Layout to Minimize Dispatching Time
}

\author{
A., Saptari ${ }^{1}$, A., Azlan ${ }^{2}$ and E., Mohamad ${ }^{3}$ \\ ${ }^{1}$ Department of Industrial Engineering, President University, \\ Jl. Ki Hajar Dewantara, Kota Jababeka, Cikarang Baru, Bekasi 17550 - Indonesia \\ ${ }^{2,3}$ Faculty of Manufacturing Engineering, Universiti Teknikal Malaysia Melaka, \\ Hang Tuah Jaya, 76100 Durian Tunggal, Melaka, Malaysia. \\ Email: *1adi.saptari@president.ac.id, "2alyaanorazlan@gmail.com; ${ }^{* 3}$ effendi@utem.edu.my
}

\begin{abstract}
Reorganizing a layout entails a massive adjustment and thorough planning is essential before a new layout implemented. This project is to reorganize layout at dispatching area of a manufacturing industry which produces apparel accessories products. Current arrangement at the dispatching area of the company shows an interrupted flow path of activities and scattered of queuing cartons at area of activities in the dispatching line which brought to operating issues. The project aims to identify problem in current arrangement of dispatching layout, analyze the the problem and propose an alternative layout that reduces dispatching time. Time studies were applied to collect data on current performance, developing alternative arrangement, and evaluation the alternative through Witness simulation. The finding showed total dispatching time of current layout consumes 30.77 minutes to complete one dispatching job with distance travel of 162.83 meters. Better alternative layout is developed by the approach of facility planning process. Results showed the dispatching time has reduced by $32.79 \%$, which the alternative layout only consumes 20.68 minutes to complete one dispatching job with shorter distance travel of 109.44 meters.
\end{abstract}

Keywords: dispatching time, layout planning, simulation.

\begin{abstract}
Abstrak
Menata tata letak memerlukan usaha besar, oleh karenanya perencanaan menyeluruh sangat penting sebelum implementasi dilaksanakan. Studi ini adalah untuk mengatur ulang tata letak di area pengiriman industri manufaktur yang menghasilkan produk aksesoris pakaian jadi. Pengaturan saat ini di area pengiriman menunjukkan alur kegiatan yang tidak teratur dan adanya antrian di jalur pengiriman yang membawa masalah operasi. Studi ini bertujuan untuk mengidentifikasi masalah dalam pengaturan tata letak pengiriman saat ini, menganalisis masalah dan mengusulkan tata letak alternatif yang dapat mengurangi waktu pengiriman. Studi waktu digunakan untuk mengumpulkan data tentang kinerja saat ini, mengembangkan pengaturan alternatif, dan mengevaluasi alternatif melalui simulasi Witness. Temuan menunjukkan waktu pengiriman total tata letak saat ini 30,77 menit untuk menyelesaikan satu pekerjaan pengiriman dengan jarak tempuh 162,83 meter. Tata letak alternatif yang lebih baik dikembangkan oleh pendekatan aliran proses perencanaan fasilitas. Hasilnya menunjukkan waktu pengiriman telah berkurang sebesar $32,79 \%$, yang tata letak alternatif hanya mengkonsumsi 20,68 menit untuk menyelesaikan satu pekerjaan pengiriman dengan jarak tempuh lebih pendek dari 109,44 meter.
\end{abstract}

Kata kunci: dispatching time, perencanaan tata letak, simulasi.

\section{Introduction}

Layout of production facilities is the basic integration phase in designing a productive system. Layout can be described as an arrangement of elements included within a manufacturing plant such as machineries and materials flows from one machine or department to another (Khoshnevisan et al., 2003). The arrangement appears to minimize costs that may related to the plant for instance cost of material handling with regards to the limitation that may encounter due to the plant layout arrangement (Chen et al., 2010). Such arrangement is related to design of processes, layout of the location, and workers' adjustment into the work area as well as machines and systems activities in the physical space environment. 
Facility layout design is associated with organizing, searching, locating equipments and manufacturing support departments to achieve an optimum overall production time, maximize operational flexibility and arrangements, maximizing revenue and maximizing work in factory output in line with production schedule (Meller and Gau, 1996). Appropriate experimentation and analysis when designing facility layout helps lead to production performance (Ertay and Ruan, 2006). Layout with less manufacturing lead time, aid to increase throughput and increase overall productivity and efficiency of plant can be considered as effective layout (Drira et al., 2007). To decide the arrangement of layout, way of parts move from one department to another department is need to be considered. Still, it is affected by number of machines, space availability and correspondence of production process and usage of material handling system (Thai, 2006).

This study was performed at apparel manufacturer where its main business is to manufacture and supply apparel accessories. The production is accordance to product demand, make it has mixed of batch and job shop layout profile. The study concentrated on dispatching department to reduce dispatching time whereby deals with carton volumes, carton sizes, different regions to dispatch and different dispatch time. Issue faced is unorganized activities' arrangement that involved carton picking area, palletizing area, wrapping area and storage area, resulted in high distance travel and time travel. A feasible layout arrangement is to be accomplished in minimizing current dispatching process time. Witness simulation is used to depicts the current acitivities' arrangement and visualizes the scattered pattern of queuing cartons.

\section{Research Background}

Manufacturing company has allocated most of their resources in obtaining the best layout. It plays a big role in determining the capability of the manufacturing production. Facility planning is an essential function to ensure the successful establishment of a production operation (El-Baz, 2004). Besides, it considers the impact of layout planning to handling and maintenance cost. An efficient layout planning can reduce operational cost and contribute to the overall production efficiency (Tompkins et al., 2003). Layout planning involves on arranging, locating and distributing the equipment and in the same time supporting the services involve in the manufacturing processes (Huang, 2003). This is due to achieving the optimization of cycle time, flexibility, work-in-process item (WIP) and factory output.

Both layout optimization and simulation are tasks which are vital to every facility planning and layout study (Yang et al., 2011). In facility planning analysis, simulation technique is used in order to get a clear picture of the layout problem. Simulation technique is an excellent tool to measure and evaluate possible arrangement in optimizing a layout (Grajo, 1996). Generally, simulation process is to imitate the operation of a real-world process or system over time. It involves development of an artificial scenario of a system and the experimentation of artificial history to illustrate assumption regarding on the operation characteristics of the real system (Aleisa and Lin, 2005). Simulation designs a dynamic model of an actual dynamic system for the reason of either understanding the behavior of the system or evaluating various strategies, within the limits imposed by one or more criteria, for the operation of the system (Banks et al., 2010).

\section{Methodology}

\subsection{Problem Formulation}

Two types of data collection which are qualitative and quantitative are collected as shown in Table 1. The collection of data was done through quantitative measure, observation and also informal interview with related person. Simulation study has sets of steps to conduct to a model builder in a systematic and well organized simulation study (Ingalls, 2002). The working sequences of simulation step starts with model conceptualization, data collection, model translation, verification, validation, experimental design, production runs and analysis, additional runs, documentation and reporting and implementation as depicted in Figure 1. 
Table 1. Data collection

\begin{tabular}{|c|c|c|c|}
\hline \multicolumn{2}{|r|}{ Quantitative data } & \multicolumn{2}{|r|}{ Qualitative data } \\
\hline a) & Number of carton at each area of activities & & \\
\hline b) & Arrival time of carton at dispatching area & & \\
\hline c) & Processing time of each activities & a) & Current arrangement of area of activities \\
\hline d) & Amount area of each activities & & \\
\hline e) & Monthly dispatching carton's quantity & & \\
\hline
\end{tabular}

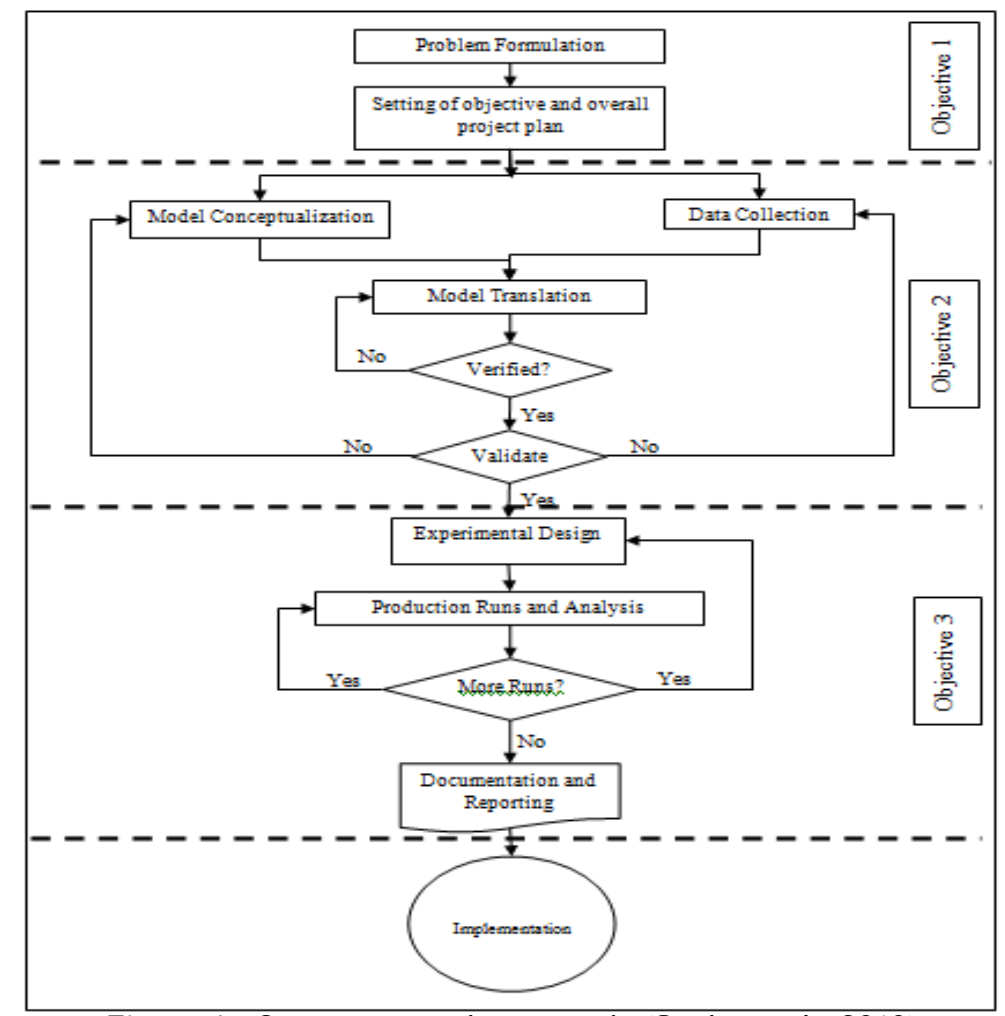

Figure 1. Steps in a simulation study (Banks et al., 2010)

\subsection{Dispatching Line of the Case Company}

The current dispatching line layout is as shown in Figure 2. In the dispatching system, the carton's flow is shown in Figure 3. The activities involved are arrival of cartons from production, sorting up of cartons to palletizing area, palletizing, wrapping, sending to storage customer region and dispatching.

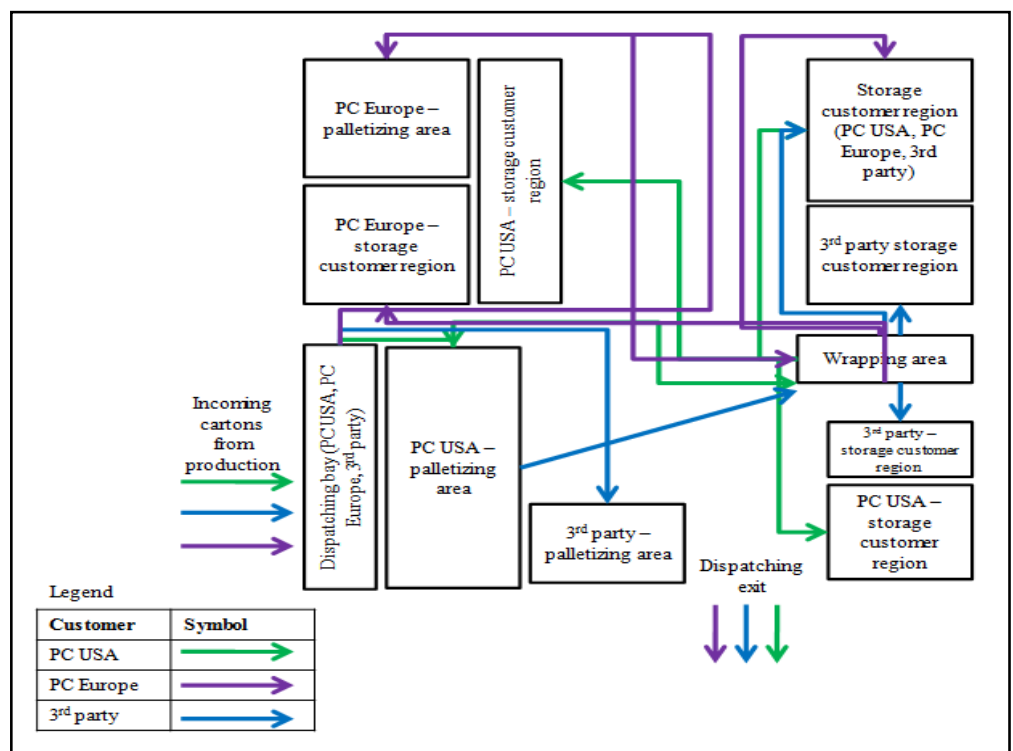

Figure 2. Current dispatching line layout of case company 


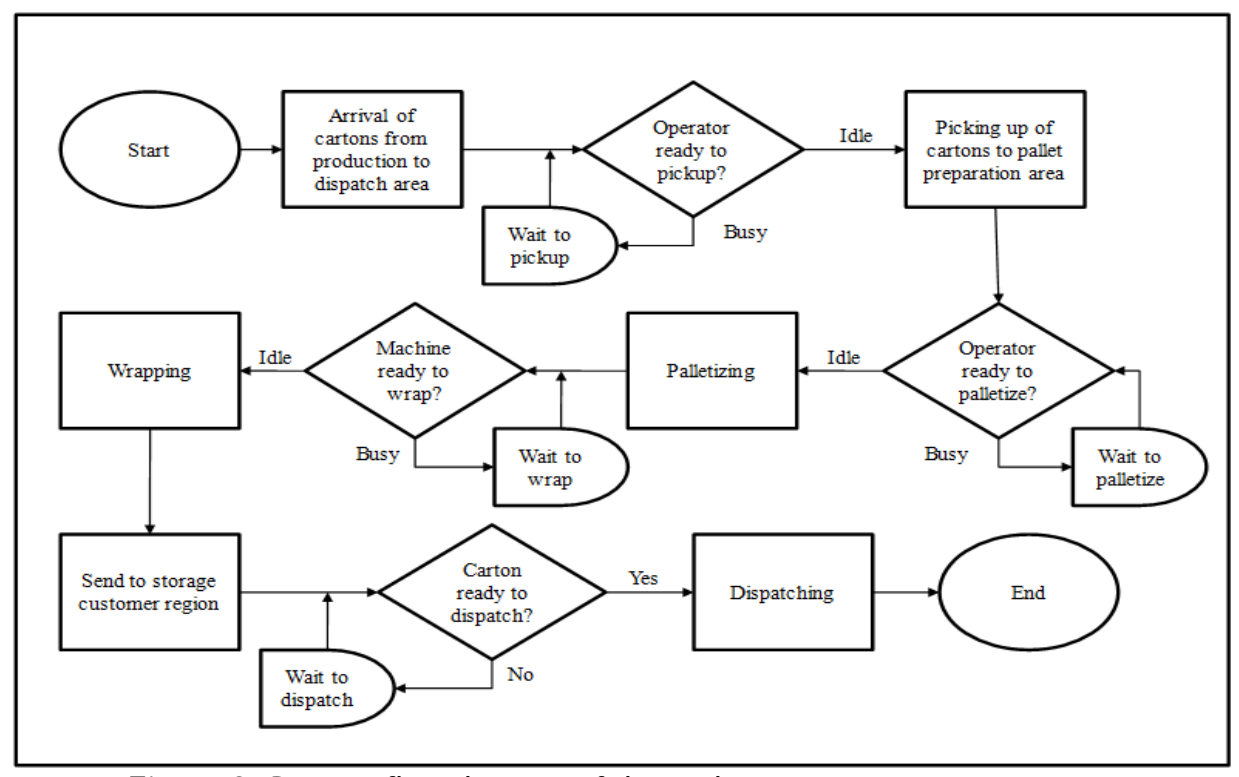

Figure 3. Process flow diagram of dispatching system in case company

\subsubsection{System Model}

A dispatching line model which represents the dispatching line was developed. Entities that involved are operators, machine and cartons and all of its components are summarized in Table 2.

Table 2. System model and their components

\begin{tabular}{|c|c|c|c|c|c|}
\hline System & Entities & Attributes & Activities & Events & State variables \\
\hline $\begin{array}{c}\text { Dispatching } \\
\text { line }\end{array}$ & $\begin{array}{c}\text { Oprival time of } \\
\text { cartons, } \\
\text { machine } \\
\text { and carton } \\
\text { processing time } \\
\text { for each process } \\
\text { and dispatch } \\
\text { schedule of carton }\end{array}$ & $\begin{array}{c}\text { Pick up } \\
\text { process, } \\
\text { palletizing } \\
\text { process and } \\
\text { wrapping } \\
\text { process }\end{array}$ & $\begin{array}{c}\text { Arrival of cartons } \\
\text { at dispatching line } \\
\text { and departure of } \\
\text { cartons from } \\
\text { system. }\end{array}$ & $\begin{array}{c}\text { Number of cartons } \\
\text { waiting at each } \\
\text { process and waiting } \\
\text { to be dispatched } \\
\text { out from system }\end{array}$ \\
\hline
\end{tabular}

\subsubsection{Conceptual Modeling of Dispatching Line}

For this project, conceptual modeling involves input and output of the conceptual modeling for dispatching line as well as model of content for the dispatching line. The inputs or experimental factors and the outputs or responses factors are as summarized in Table 3. Model of content of conceptual modeling involves scopes of simulation and level detail of simulation. The inputs or experimental factors are correctly interpreted and the outputs or responses are attained accurate values that are probably useful to consider in term of the scope and level of detail. The scope of the model must be sufficient to provide a linkage between the experimental factors and the responses. The scope of the model must also include any processes that interconnect with this flow such that they have significant impact on the responses, the meaning of significant being defined by the level of model accuracy required. The scope of simulation for dispatching line is summarized in Table 4.

Table 3. Input and output of conceptual modeling

\begin{tabular}{|llll|}
\hline & Inputs (experimental factors) & \multicolumn{1}{c|}{ Outputs (responses) } \\
\hline i. & Arrival time of cartons & i. & Number of cartons waiting at each process \\
ii. & Processing time for each activities & ii. & Total processing time for each activities \\
\hline
\end{tabular}

Table 4. Scope of simulation for dispatching line

\begin{tabular}{|c|c|c|}
\hline Components & Include/exclude & Justification \\
\hline Carton & Include & $\begin{array}{l}\text { Required for arrival time of cartons and dispatch } \\
\text { schedule of carton }\end{array}$ \\
\hline Operator & Include & $\begin{array}{l}\text { Required for processing time for carton pick up } \\
\text { and palletizing process }\end{array}$ \\
\hline Machine & Include & Required for processing time for wrapping process \\
\hline
\end{tabular}

The level of detail represents the components defined within the scope and their interconnection 
with the other model components with sufficient accuracy. This can be considered with respect to the impact on the model's responses. The level detail of simulation production system is summarized in Table 5. To simplify the dispatching system model, there are some assumptions and simplifications. The assumptions are associated with dispatching system model translation whereby the order sequence of cartons is based on the distribution of the arrival time of cartons entering the dispatch system. As for simplification, since the operator picks up certain number of cartons on one pallet which depends on the purchase order, thus, the cartons that enter the system will be treated as one part. Hence, one part in the simulation will represent one purchase order. Also, the cartons are considered as always ready to go out from the system once it is stored in the storage customer region.

Table 5. Level of detail of simulation for dispatching line

\begin{tabular}{|c|c|c|}
\hline Components & $\begin{array}{l}\text { Include/ } \\
\text { exclude }\end{array}$ & Justification \\
\hline Carton & Include & Required to determine arrival time of carton \\
\hline $\begin{array}{l}\text { Operator: } \\
\text { Pick up cartons } \\
\text { Palletize cartons } \\
\text { Send to storage } \\
\text { customer region }\end{array}$ & $\begin{array}{l}\text { Include } \\
\text { Include } \\
\text { Exclude }\end{array}$ & $\begin{array}{l}\text { Required for picking up processing time } \\
\text { Required for palletizing processing time } \\
\text { Not required as this activity is a complementary to next process }\end{array}$ \\
\hline $\begin{array}{l}\text { Machine: } \\
\text { Wrap cartons }\end{array}$ & Include & Required for wrapping processing time \\
\hline
\end{tabular}

The data collection is on processing time for sorting up carton, palletizing and wrapping. However, carton inter-arrival time and processing time of carton storing are excluded as the carton is assumed always available to be processed and the labor is assumed to be available when needed. The data were collected for a period of one week which gives 75 readings for each activity. The total processing time taken in a week is $2,313.65$ minutes or 38.56 hours. The data are taken based on daily basis on morning working hour and evening working hour, from $8.30 \mathrm{a} . \mathrm{m}$. until $4.00 \mathrm{p}$.m. The product data was taken randomly collected since it was hard to identify what product inside carton since already packaged as arrive at the dispatching area.

\subsubsection{Model Translation}

The model was run for warming up session for 100 days in which the average of cycle time and lot products produced per day were stable. This is shown in Figure 4. Then, 10 independent replications are generated and ran with a length of replication duration of two days to obtain the average of carton's processing time to be dispatched out. The results of the replication are as tabulated in Table 6.

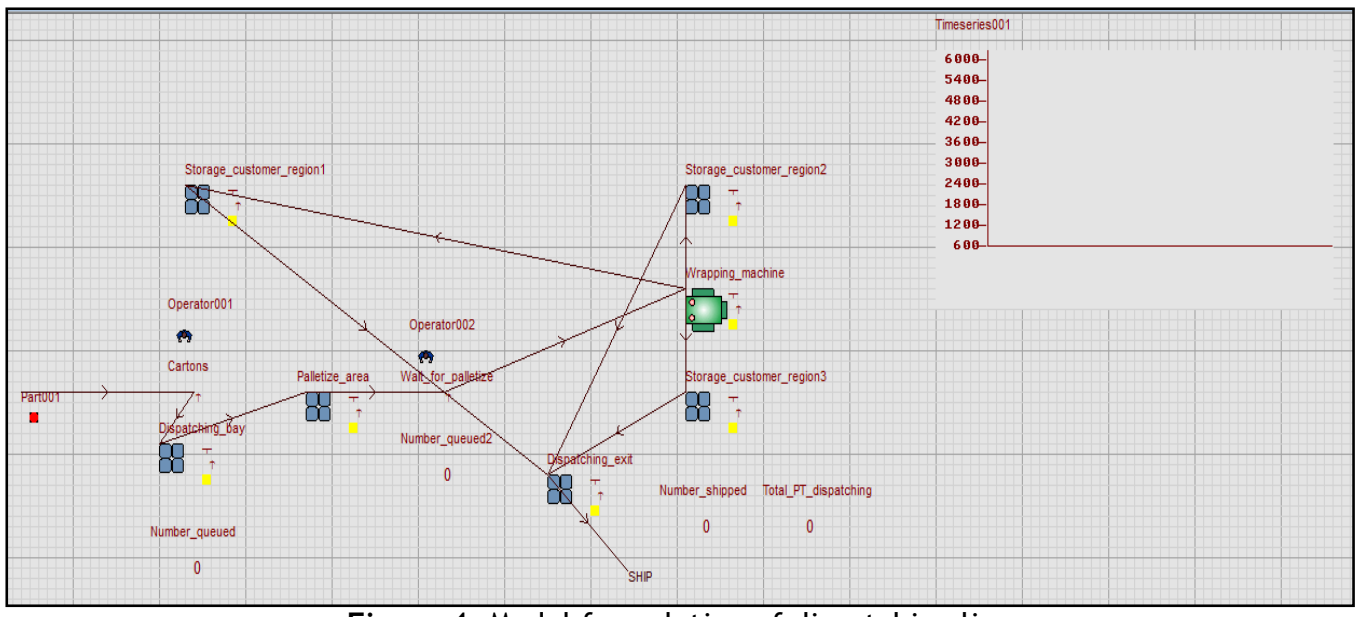

Figure 4. Model formulation of dispatching line

Table 6. Result of replication of average total processing time 


\begin{tabular}{|c|c|}
\hline Replication & Average total processing time of dispatching line (min) \\
\hline 1 & $111,057.18$ \\
\hline 2 & $111,055.82$ \\
\hline 3 & $111,046.21$ \\
\hline 4 & $111,045.33$ \\
\hline 5 & $111,042.26$ \\
\hline 6 & $111,042.93$ \\
\hline 7 & $111,042.75$ \\
\hline 8 & $111,039.80$ \\
\hline 9 & $111,033.78$ \\
\hline 10 & $111,030.43$ \\
\hline Average & $\mathbf{1 1 1 , 0 4 3 . 6 5}$ \\
\hline
\end{tabular}

\subsubsection{Verification and Validation}

Verification is applied by comparing a flow diagram with the simulation model as shown in Figure 5 and the number of queuing pallet as shown in Table 7. The output of simulation model is closely examined under a variety of input parameters setting. For validation purposes, the average processing time was used. The validation requires statistic description, distribution identification, normality test and determination of $p$-value. The data of replication run of the average processing time of dispatching is undergone step by step of the data validation which are within the $95 \%$ of confident interval to ensure the simulation model is accurately represents the real dispatching line. In this stage, the data of replication run were successfully validated within the $95 \%$ confidence interval.

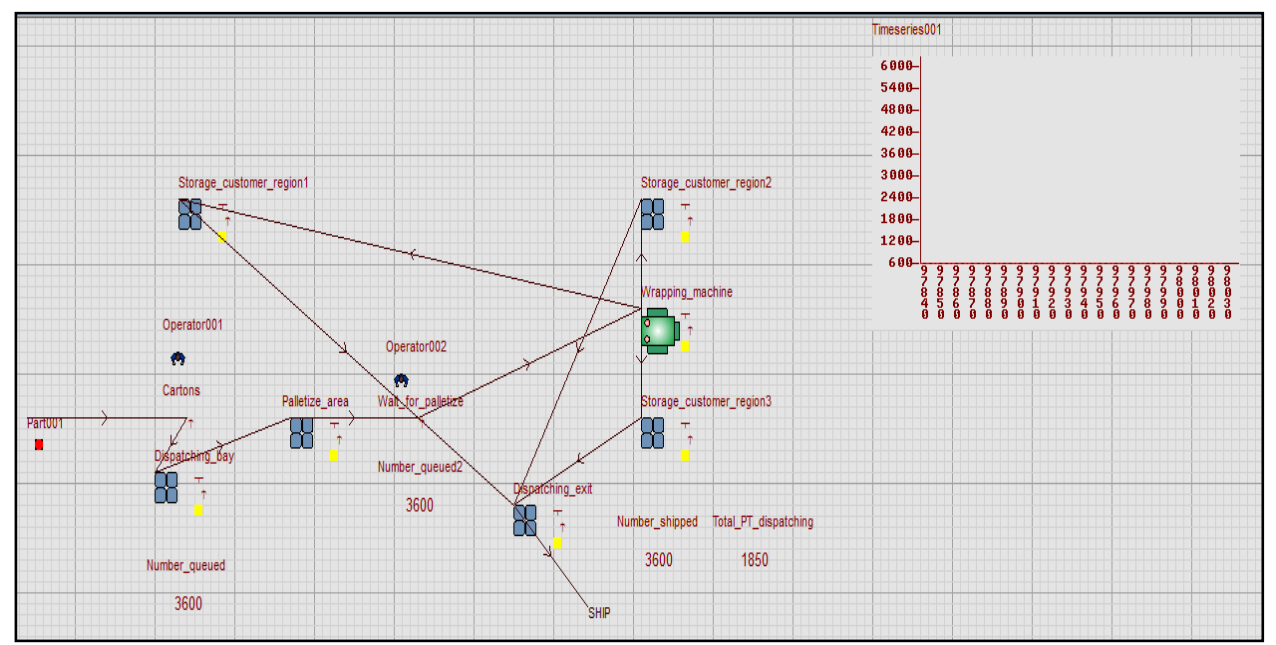

Figure 5. Simulation model of dispatching line.

Table 7. Comparison of number of queued pallet at areas of activities

\begin{tabular}{|c|c|c|}
\cline { 2 - 3 } \multicolumn{1}{c|}{} & \multicolumn{2}{c|}{ Number of queued pallet (unit in pallet) } \\
\hline Area & Historical data & Simulation \\
\hline Carton picking area & 24 & 24 \\
\hline Palletizing area & 126 & 126 \\
\hline Wrapping area & 26 & 26 \\
\hline Storage area & 60 & 60 \\
\hline
\end{tabular}

\section{Reorganization of Alternative Layout}

\subsection{Model Experimentation}

The alternative layout is reorganized by identifying the layout according to activities' sequence as shown in Figure 6. Based on Figure 7, the location of the area was then reorganized by following the activities' sequence. This arrangement considered unmovable activity and loading exit location. Then other activities are reorganized into the sequence. Next was to determine the space requirement as shown in sample calculation and the results for all areas are tabulated in Table 8. 


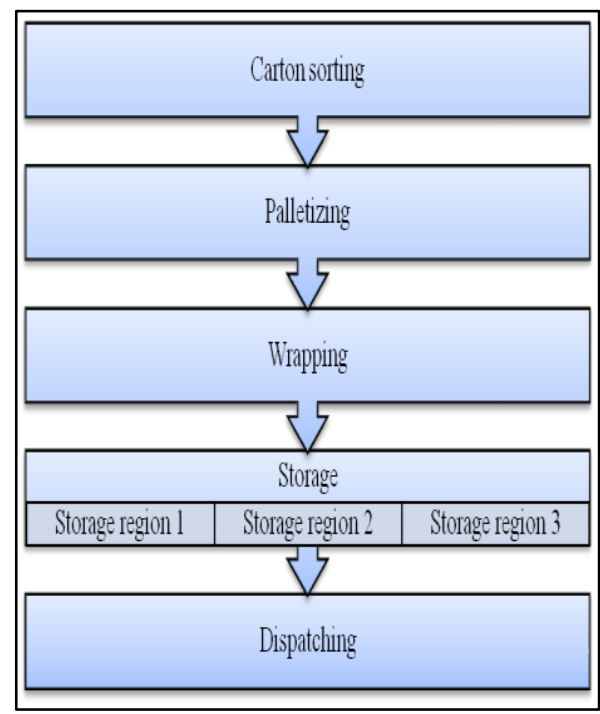

Figure 6. Sequence of activities

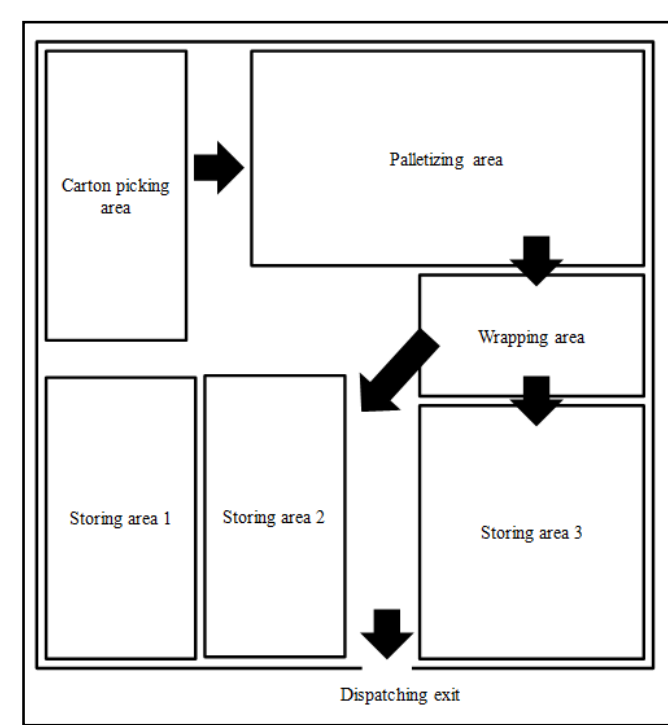

Figure 7. Reorganization of layout

Sample calculation on determining space requirement for wrapping area: Area of one pallet $=1.2 \mathrm{~m}^{2}$

Maximum numbers of pallets queued at wrapping area $=26$ pallets

Space requirement $=1.2 \mathrm{~m}^{2} \times 26$ pallets $=30.92 \mathrm{~m}^{2}$

Table 8. Summary result of space requirement area

\begin{tabular}{|c|c|c|}
\hline Area & $\begin{array}{c}\text { Maximum number of pallet } \\
\text { queuing at a time (unit) }\end{array}$ & $\begin{array}{c}\text { Space requirement } \\
\left(\mathbf{m}^{2}\right)\end{array}$ \\
\hline Carton sorting & 24 & 28.33 \\
\hline Palletizing & 126 & 151.33 \\
\hline Wrapping & 26 & 30.92 \\
\hline Storage & 60 & 71.97 \\
\hline
\end{tabular}

Last step was to conduct storage layout planning. $A B C$ inventory classification is performed to identify and separate items' annual total dispatch. In this case, the storage layout is classified according to fast, medium and slow moving item. The fast moving item is located near to the loading exit, followed by medium moving item and slow moving item. Total number of 1,464 products are listed its dispatch quantity in carton, dispatch frequency and total dispatch carton in a year. The cumulative of the annual total dispatch carton is then calculated as percentage as shown in Table 9. The products in $80 \%$ of the annual total dispatch carton percentage are classified as A, products in $15 \%$ are classified as $B$ and products in $5 \%$ are classified as $C$. Products in A classification is grouped as fast moving item, B classification is grouped as medium moving item, and C classification is grouped as slow moving item.

Table 9. Summary result of $A B C$ inventory classification

\begin{tabular}{|c|c|c|c|}
\hline $\begin{array}{c}\text { Total } \\
\text { number of } \\
\text { product }\end{array}$ & $\begin{array}{c}\text { Percentage of total } \\
\text { number of product (\%) }\end{array}$ & $\begin{array}{c}\text { Percentage of annual total } \\
\text { dispatch carton (\%) }\end{array}$ & Classification \\
\hline 271 & 18.51 & 80.07 & $\mathrm{~A}$ \\
\hline 378 & 25.82 & 15.02 & $\mathrm{~B}$ \\
\hline 815 & 55.67 & 4.92 & $\mathrm{C}$ \\
\hline
\end{tabular}

\subsection{Comparison of Current and Alternative Layout}

Simulated model shows the current layout has interrupted flow and unorganized queuing cartons at some area. The current and alternative layout are as shown in Figure 8 and 9 respectively. Based on data collected, 75 readings are taken for one week gives total of processing time is 2,313 minutes. It can be manipulated that one complete work equals to one reading. Hence, it takes 30.84 minutes to do one complete work of activities. By referring to the current layout, total distance taken to do one complete work of activities is 162.83 meter. Thus, 1 meter distance travel takes 0.189 minutes. This is then used to determine time consumed for each of the distance travel by operator. Mode of transportation used is forklift and width of aisle is 2.74 meter. The distance travel is calculated using rectilinear distance and the total time consume for distance travel by each activities are calculated and tabulated as shown in Table 10. 


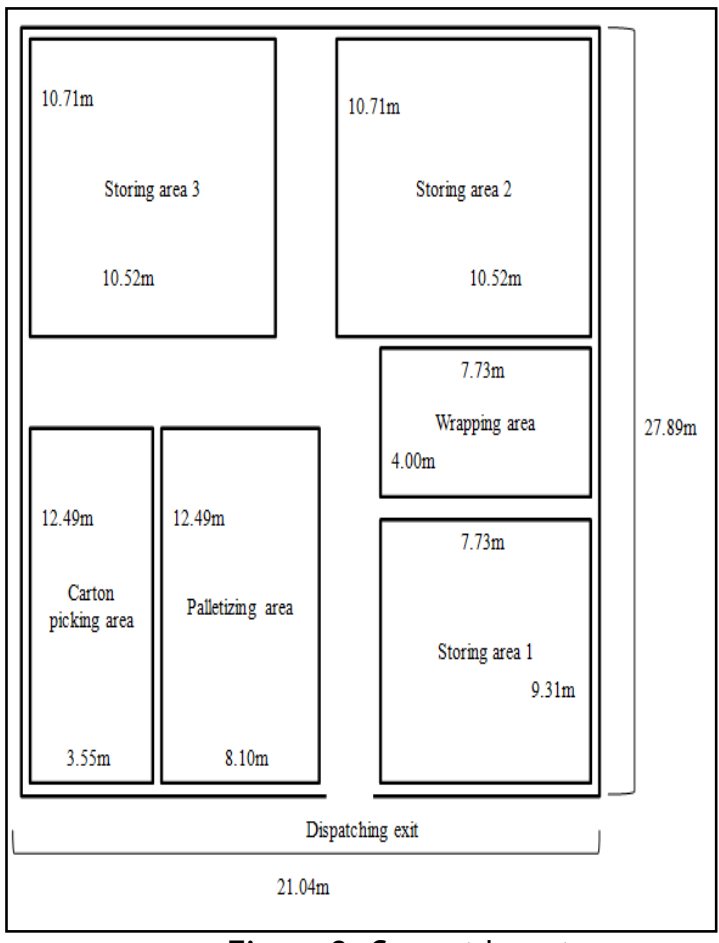

Figure 8. Current layout

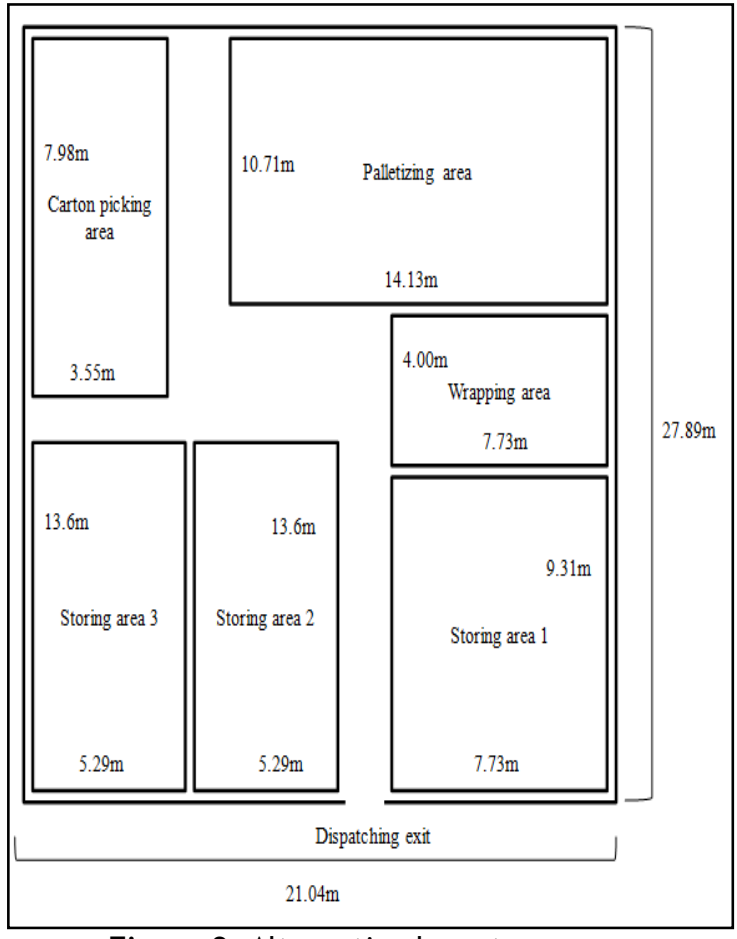

Figure 9. Alternative layout

Table 10. Comparison of current and alternative layout

\begin{tabular}{|c|c|c|c|c|c|}
\hline \multicolumn{2}{|c|}{ Activities } & \multicolumn{2}{c|}{ Current layout } & \multicolumn{2}{c|}{ Alternative layout } \\
\hline \multirow{2}{*}{ From } & To & $\begin{array}{c}\text { Distance } \\
\text { travel }(\mathbf{m})\end{array}$ & $\begin{array}{c}\text { Time } \\
\text { consumed } \\
(\mathbf{m i n})\end{array}$ & $\begin{array}{c}\text { Distance } \\
\text { travel }(\mathbf{m})\end{array}$ & $\begin{array}{c}\text { Time } \\
\text { consumed } \\
(\mathbf{m i n})\end{array}$ \\
\hline Carton picking area & Palletizing area & 17.91 & 3.38 & 11.58 & 2.19 \\
\hline Palletizing area & Wrapping area & 18.27 & 3.45 & 12.59 & 2.38 \\
\hline \multirow{2}{*}{ Wrapping area } & Storage area 1 & 15.76 & 2.98 & 13.76 & 2.60 \\
\cline { 2 - 6 } & Storage area 2 & 21.33 & 4.03 & 16.05 & 3.03 \\
\cline { 2 - 6 } & Storage area 3 & 21.33 & 4.03 & 18.64 & 3.52 \\
\hline Storage area 1 & \multirow{2}{*}{$\begin{array}{c}\text { Dispatching } \\
\text { Storage area 2 }\end{array}$} & 9.89 & 1.87 & 9.89 & 1.87 \\
\cline { 4 - 6 } & exit & 29.17 & 5.51 & 10.82 & 2.04 \\
\cline { 3 - 6 } Storage area 3 & 29.17 & 5.51 & 16.11 & 3.04 \\
\hline \multicolumn{2}{|c|}{ TOTAL } & $\mathbf{1 6 2 . 8 3}$ & $\mathbf{3 0 . 7 7}$ & $\mathbf{1 0 9 . 4 4}$ & 20.68 \\
\hline
\end{tabular}

The alternative layout reduced the total distance travel which cut off distance of 53.39 meters. Also, the time consumed is reduced by $32.79 \%$. Therefore, the alternative layout helps to reduce the dispatching time which leads to the reduction in distance travel by the operator. As the alternative layout has reduced the distance travel and time consumed of total dispatching time, space utilization can be evaluated. The area of each activities of current layout is compared with the alternative layout as shown in Table 11. The percentage area can be utilized about $36.11 \%$. This means the current layout should cut off $36.11 \%$ from the current carton sorting area, resulted in shorter distance travel. For palletizing area, the percentage area should be utilized is $49.58 \%$ by should add on $49.58 \%$ of area to manage queuing cartons. For both Storage 2 and 3, the percentage area should be utilized is $36.12 \%$. This same goes to carton sorting area whereby percentage area should be utilized is $36.12 \%$, resulted in shorter distance travel. This assessment done to identify necessity of area for each activity in accordance with their requirements to the reduction of dispatching time. 
Table 11. Comparison of current and alternative layout

\begin{tabular}{|c|c|c|c|}
\hline Area & $\begin{array}{c}\text { Current } \\
\text { layout } \\
\left(\mathbf{m}^{2}\right)\end{array}$ & $\begin{array}{c}\text { Alternative } \\
\text { layout }\left(\mathbf{m}^{2}\right)\end{array}$ & $\begin{array}{c}\text { Proposal of percentage area to be used for each } \\
\text { activity by implementing alternative layout (\%) }\end{array}$ \\
\hline Carton picking & 44.34 & 28.33 & 36.11 \\
\hline Palletizing & 101.17 & 151.33 & 49.58 \\
\hline Wrapping & 30.92 & 30.92 & 0 \\
\hline Storage 1 & 71.97 & 71.97 & 36.12 \\
\hline Storage 2 & 112.67 & 71.97 & 36.12 \\
\hline Storage 3 & 112.67 & 71.97 & \\
\hline TOTAL & $\mathbf{4 7 3 . 7 4}$ & $\mathbf{4 2 6 . 4 9}$ & \\
\hline
\end{tabular}

\section{Conclusion}

This paper studies on the development of alternative layout for dispatching area. The activities involved the area are carton sorting, palletizing, wrapping and storage. Simulation method is used to imitate the operation of a real-world system over time. From the simulation it was identified that palletizing activities gave the most number of queueing carton. Alternative layout was developed with the approach of facility planning process. The assessment was performed on distance travel, space requirement for each area of activities, and travel time. Simulation results showed that proposed new dispatching layout provides reduction of total dispatching time by $32.79 \%$, from 30.77 minutes to 20.68 minutes to complete one dispatching job and shorter travel distance in average from 162.83 meters to 109.44 meters.

\section{References}

1. M. Khoshnevisan, S. Bhattacharya, and F. Smarandache. (2003). “Optimal Plant Layout Design for Process-focused Systems".

2. T. M. Chen, C. C. Chen, S. P. Chuang. (2010). “A Simulated Annealing-based Approach for Dynamic Facility Planning Department of Vehicle Engineering”, National Taipei University of Technology, Taipei, Taiwan, Department of Information Management, Huafan University, Taipei, Taiwan, pp. 1291.

3. R. D. Meller, and K. Y. Gau. (1996). "The Facility Layout Problem: Recent and Emerging Trends and Perspectives", Journal of Manufacturing Systems, vol. 15, no. 5, pp. 1 - 16.

4. T. Ertay, and D. Ruan. (2006). “Integrating Data Envelopment Analysis and Analytic Hierarchy for the Facility Layout Design in Manufacturing Systems”, Information Sciences 176, pp. 237 - 262.

5. A. Drira, H. Pierreval, and S. Hajri-Gabouj. (2007). “Facility Layout Problems: A Survey”. Annual Reviews in Control, pp. 255-267.

6. A. B. Thai. (2006). "Evaluation of Using Swarm Intelligence to Produce Facility Layout Solutions", University of Louisville, pp. 11-12.

7. M. A. El-Baz. (2004). "A Genetic Algorithm For Facility Layout Problems Of Different Manufacturing Environments”, Computers \& Industrial Engineering, pp. 233 - 246.

8. J. Tompkins, Y. Bozer, E. Frazelle, J. Tanchoco, and J. Trevino. (2003). “Facility Planning”, John Wiley and Sons, New York.

9. H. Huang. (2003). "Facility Layout Using Layout Modules", The Ohio State University.

10. L. Yang, J. Deuse, and M. Droste. (2011). “Energy Efficiency at Energy Intensive Factory - A Facility Planning Approach”, Chair of Industrial Engineering, TU Dortmund University, Dortmund, Germany, pp. 699. 
11. E. S. Grajo. (1996). "Strategic Layout Planning and Simulation for Lean Manufacturing a Layout Tutorial", In Proceedings of the 1995 Winter Simulation Conference, Piscataway, New Jersey: Institute of Electrical and Electronics Engineers, pp. 564-568.

12. E. E. Aleisa, and L. Lin. (2005). "For Effective Facilities Planning: Layout Optimization Then Simulation, Or Vice Versa", Proceedings of the 2005 Winter Simulation Conference, pp. 1381-1383.

13. J. Banks, J.S. Carson, B.L. Nelson and D.M. Nicol. (2010). "Discrete-Event System Simulation”, Pearson, 5th ed.

14. R.G. Ingalls. (2002). "Introduction to Simulation", Proceedings of the Winter Simulation Conference. 